\title{
PEMANTAUAN PERUBAHAN GARIS PANTAI JANGKA PANJANG DENGAN TEKNOLOGI GEO-SPASIAL DI PESISIR BAGIAN BARAT KABUPATEN TUBAN, JAWA TIMUR
}

\author{
M. Arif Zainul Fuad 1,2, Nena Yunita1, Rarasrum D. Kasitowati 1, Nurin Hidayati1,2, \\ Aida Sartimbul1,2 \\ 1Program Studi Ilmu Kelautan, Fakultas Perikanan dan Ilmu Kelautan, \\ Universitas Brawijaya \\ ${ }^{2}$ Marine Resources Exploration and Management Research Group (MEXMA) FPIK-UB \\ Jl. Veteran, Malang- 65145 \\ Email: fuad_maz@ub.ac.id
}

\begin{abstract}
Abstrak
Pesisir Tuban bagian barat berpotensi mengalami perubahan garis pantai yang dipengaruhi oleh adanya pembangunan di wilayah pesisir berupa pelabuhan, permukiman, budidaya perikanan, dan reklamasi. Oleh karena itu perlu adanya pemantauan dinamika pesisir, kerusakan pesisir, dan perencanaan pembangunan pada kawasan pesisir. Penelitian ini bertujuan untuk mengetahui tren perubahan garis pantai jangka panjang dalam kurun waktu 1973-2018 dan memprediksi garis pantai di Tuban bagian barat. Penelitian ini memanfaatkan teknologi penginderaan jauh dan Sistem Informasi Geografis (SIG) untuk pemantauan perubahan garis pantai di pantai dengan Citra Landsat tahun 1973, 1988, 1998, 2008, 2017, and U.S Army Map Service tahun 1964. Perhitungan perubahan garis pantai menggunakan aplikasi Digital Shoreline Analysis System (DSAS) dengan menggunakan metode Net Shoreline Movement (NSM) dan End Point Rate (EPR) untuk menganalisis perubahan garis pantai yang telah terjadi, sedangkan metode Linear Regression Rate (LRR) digunakan untuk memprediksi perubahan garis pantai pada 10 tahun mendatang. Hasil penelitian menunjukkan bahwa di Pantai Tuban bagian barat akresi terbesar terjadi di Desa Remen yaitu sejauh $323 \mathrm{~m}$ dengan laju akresi sebesar 7,32 m/tahun. Sebaliknya abrasi tertinggi dialami oleh Desa Mentosa dengan rata-rata jarak abrasi sebesar 181,90 m dan rata-rata laju abrasi sejauh 4,11 m/tahun. Prediksi perubahan garis pantai untuk 10 tahun kedepan mengindikasikan terjadinya akresi di Desa Glodonggede dan abrasi di Desa Mentosa.
\end{abstract}

Kata kunci: Garis Pantai, Akresi, Abrasi, Pemantauan, DSAS

\section{Abstract}

The western Tuban coast has the potential to experience shoreline changes influenced by the development in coastal areas in the form of ports, settlements, aquaculture and reclamation. Therefore, it is necessary to monitor coastal dynamics, coastal damage, and development planning in coastal areas. This study aims to determine the trend of longterm shoreline changes in the period 1973-2018 and predict coastlines in the western part of Tuban. This study uses remote sensing technology and Geographic Information System (GIS) to monitor changes in coastlines on the western coast of Tuban Regency with Landsat imagery in 1973, 1988, 1998, 2008, 2017, and US Army Map Service in 1964. Calculation of shoreline changes using Digital Shoreline Analysis System (DSAS) 
application using Net Shoreline Movement (NSM) and End Point Rate (EPR) methods to determine shoreline changes, while the Linear Regression Rate (LRR) method is used to predict shoreline changes in the next 10 years. The results showed that in the western part of Tuban Beach the largest accretion occurred in the village of Remen which was 323 $m$ with an accretion rate of $7.32 \mathrm{~m} /$ year. Conversely, the highest abrasion was experienced by Mentosa Village with an average abrasion distance of $181.90 \mathrm{~m}$ and an average abrasion rate of $4.11 \mathrm{~m} /$ year. Predictions of shoreline changes for the next 10 years indicate the occurrence of accretion in Glodonggede Village and abrasion in Mentosa Village

Keywords: Shoreline, Accretion, Abrasion, Monitoring, DSAS

\section{PENDAHULUAN}

Garis pantai merupakan batas pertemuan antara daratan dan perairan yang akan mengalami perubahan dari waktu ke waktu. Proses perubahan garis pantai diakibatkan oleh faktor pengikisan (abrasi) dan penambahan / akresi (Arief, et al., 2011).

Akresi dan abrasi pantai terjadi karena adanya masukan sedimen dari daratan ke wilayah pesisir dan pengaruh dari faktor hidro-oseanografi yang berupa gelombang dan arus yang membawa sedimen. Apabila laju sedimen tidak sebanding dengan arus dan gelombang maka akan terjadi sedimentasi di pantai, namun apabila laju sedimen dari darat lebih kecil dari arus dan gelombang dari laut maka akan terjadi abrasi (Setyawan, 2001). Proses akresi dan abrasi mengakibatkan kondisi pantai menjadi tidak seimbang dan berdampak pada kerusakan di kawasan Pesisir (Hidayati, 2017).

Kerusakan akibat adanya akresi dapat mengakibatkan terjadinya penutupan muara sungai sehingga menimbulkan banjir. Sedangkan abrasi dapat mengakibatkan kerusakan pada akses jalan, bangunan di sekitar pesisir (rumah, pabrik, fasilitas pelabuhan), area persawahan, area pertambakan, dan area rekreasi pantai (Pranoto, 2007).

Dampak dari adanya perubahan garis pantai menandakan bahwa perlu adanya pemantauan perubahan garis pantai. Pemantauan perubahan garis pantai sangat diperlukan dalam perencanaan bangunan pelindung pantai, pendeteksi kerusakan di kawasan pesisir, dan sebagai acuan dalam pembuatan suatu kebijakan pengembangan dan pengelolaan wilayah pesisir (Marfai, et al., 2011). Pemantauan perubahan garis pantai dapat dilakukan dengan mengunakan penginderaan jauh karena dapat dilakukan pemantauan secara multi temporal dengan ketersediaan data dalam beberapa tahun (Suniada, 2015).

Pesisir Kabupaten Tuban bagian barat khususnya Kecamatan Bancar, Kecamatan Tambakboyo, dan Kecamatan Jenu memiliki aset penting seperti Pelabuhan Khusus PT. Semen Gresik, Pelabuhan Khusus PT. Holcim, Pelabuhan Khusus PLTU Tanjung Awar-awar, Pelabuhan Khusus PT. Trans Pasific Petrochemical Indotama (TPPI), Terminal Bus baru dan UPT. Pelabuhan Perikanan Bulu. Adanya beberapa bangunan jetty pelabuhan tersebut dapat menjadi faktor pemicu perubahan garis pantai di pesisir Kabupaten Tuban bagian barat karena mempengaruhi perubahan pola sebaran sedimen di sekitar pantai, sehingga dapat mengakibatkan kerusakan lingkungan serta ekosistem di pesisir.

Penelitian tentang perubahan garis pantai di Kabupaten Tuban bagian barat pernah dilakukan, salah satunya oleh Richard (2015) dengan hasil perubahan 
garis pantai tahun 1994-2013 menunjukkan intensif terjadi pada kawasan yang dilakukan pembangunan jetty pelabuhan. Namun pada penelitian tersebut mempertimbangkan kondisi pasang surut dan prediksi perubahan garis pantai pada masa yang akan datang. Parameter tersebut sangat diperlukan untuk menyamakan kondisi kedudukan pasang surut pada data citra dan mengetahui kondisi perubahan garis pantai pada waktu yang akan datang, sehingga dapat dilakukan antisipasi dan perencanaan pembangunan sebelum terjadinya kerusakan dikawasan tersebut.

Melihat adanya kekurangan pada penelitian sebelumnya dan dinamika hidrooseanografi yang terus mengalami perubahan, maka perlu dilakukan pemantauan perubahan garis pantai kembali di Pesisir Tuban bagian barat. Penelitian ini dilakukan dengan memanfaatkan aplikasi Digital Shoreline Analysis System (DSAS). Tujuan utama penelitian ini adalah untuk mengetahui perubahan garis pantai jangka Panjang kurang lebih 43 tahun pada rentang waktu tahun 1974-2017 dan melakukan prediksi perubahan garis pantai pada tahun mendatang.

\section{METODE PENELITIAN \\ Waktu dan Tempat}

Penelitian berlokasi di pesisir Tuban bagian barat pada Kecamatan Bancar, Kecamatan Tambakboyo dan Kecamatan Jenu dengan panjang garis pantai $\pm 49 \mathrm{~km}$ (Gambar 1). Pelaksanaan penelitian pada bulan Februari 2018 sampai Juni 2018. Survei lapang dilaksanakan pada tanggal 12 Juni 2018 meliputi tracking garis pantai, dan perhitungan kemiringan pantai di Panti Bulu Desa Bulumeduro, Pantai Bancar di Desa Bancar, Pantai Gadon di Desa Gadon, Pantai Surindah di Desa Temaji, Pantai Pasir Putih di Desa Remen, Pantai Mentosa di Desa Mentosa Pantai Cemara di Desa Sugiwaras.

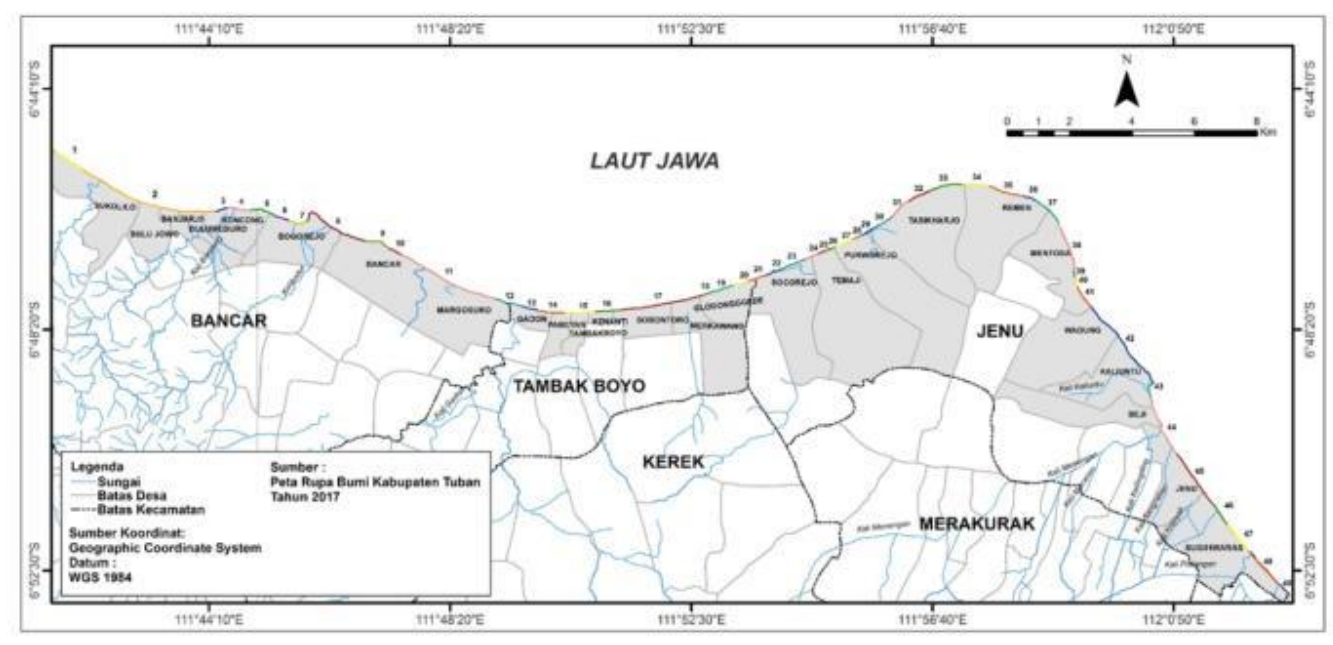

Gambar 1. Peta Lokasi Penelitian

\section{Pengumpulan Data}

Data yang diperlukan dalam penelitian ini yaitu garis pantai, kemiringan pantai dan data pasang surut saat akuisisi citra. Data garis pantai tahun 1964 didapatkan dari Peta U.S Army Map Service 5322 I, 5322 IV dan 5422 II. Data garis pantai tahun 1973, 1988, 1998, 2008, dan 2017 didapatkan dari citra Satelit Landsat yang di unduh dari United States Geological Survey (USGS) (Tabel 1). Peramalan pasang surut dilakukan dengan menggunakan Tide Model Driver (TMD). 
Tabel 1. Data Citra Landsat

\begin{tabular}{llll}
\hline No. & Citra satelit & Tanggal Akuisisi & Jenis Sensor \\
\hline 1 & Landsat 1 & $10 / 10 / 1973$ & Multispectral Scanner (MSS) \\
2 & Landsat 4 & $29 / 12 / 1989$ & Thematic Mapper (TM) \\
3 & Landsat 5 & $14 / 10 / 1998$ & Thematic Mapper (TM) \\
4 & Landsat 7 & $26 / 05 / 2008$ & Enhaced Thematic Mapper Plus (ETM+) \\
5 & Landsat 8 & $28 / 06 / 2017$ & Operational Land Imager (OLI) \\
\hline
\end{tabular}

\section{Pengolahan Data}

Garis pantai tahun 1964 didapatkan dari Peta U.S Army Map Service. Langkah pertama adalahan scanning peta dengan Flatbed Scanner, kemudian koreksi geometrik pada hasil scan tersebut untuk memberikan koordinat yang sesuai. Langkah terakhir adalah digitasi garis pantai dengan metode on screen digitizing di ArcGIS 10.3. Hasil akhir dari proses ini adalah data garis pantai Kabupaten Tuban bagian barat tahun 1964.

Citra Landsat pada masing masing tahun mengalami proses pengolahan data dengan tahapan sebagai berikut. Tahapan pertama pemotongan citra (Cropping Image) untuk meringankan proses kerja komputer. Tahapan kedua koreksi geometrik untuk memperbaiki posisi objek dalam citra sesuai dengan keadaan sebenarnya. Kemudian dilakukan koreksi geometrik dengan bantuan perangkat lunak ENVI 5.1 dengan acuan titik ground check dari hasil survei lapangan dan Peta RBI Kabupaten Tuban Tahun 2017. Tahapan ketiga koreksi radiometrik untuk mengoreksi citra yang disebabkan karena kerusakan satelit atau gangguan atmosfer (Istiqomah, et al., 2016). Koreksi radiometrik dengan menggunakan software ENVI 5.1 dengan metode Reflectance Radiometric Calibration digunakan untuk mempertajam citra, sedangkan koreksi atmosfer untuk menghilangkan gangguan atmosfer mengunakan FLAASH (Fast Line of Sight Atmospheric Analysis of Spectral Hypercubes). Tahapan ke-empat yaitu proses delineasi untuk memisahkan daratan dan perairan dalam bentuk garis pantai yang akan dianalisa dengan menggunakan teknik komposit band untuk menampilkan batas objek yang diamati (Kasim, et al., 2015). Metode deliniasi daratan dan perairan pada penelitian ini dengan menggunakan metode Modified Normalised Difference Water Index (MNDWI). Metode ini merupakan salah satu metode yang terbaik untuk dapat memisahkan daratan dan lautan (Fuad, et al. 2017). Selanjutnya mengubah data raster MNDWI menjadi data vektor dengan menggunakan metode threshold. Selanjutnya digitasi dengan metode on screen digitizing. Rumus deliniasi dengan MNDWI untuk sensor ETM+ dan TM menurut Xu (2006) adalah sebagai berikut:

$M N D W I=\frac{\text { Green }-M I R}{\text { Green }+M I R}$

Untuk Rumus MNWI untuk sensor OLI menurut Luyan Ji (2015), sebagai berikut:

$M N D W I=\frac{\text { Green }-S W I R 1}{\text { Green }+ \text { SWIR } 1}$

\section{Digital Shoreline Analysis System (DSAS) \\ Digital Shoreline Analysis System}

(DSAS) merupakan aplikasi perhitungan perubahan garis pantai secara statistik dan berbasis geospasial dengan menggunakan titik sebagai acuan pengukuran (Istiqomah, et al., 2016). Parameter yang digunakan untuk melakukkan perhitungan perubahan garis pantai dengan menggunakan DSAS terdiri dari baseline yang digunakan sebagai acuan titik 0 pengukuran perubahan garis pantai, shorelines adalah garis pantai yang dilakukan pengukuran, dan transek yang membagi menjadi beberapa pias pada garis pantai (Gambar 2). 


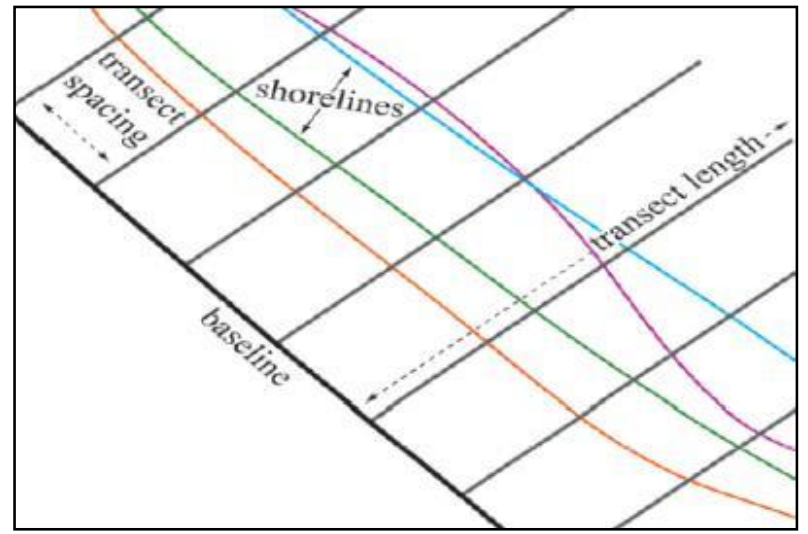

Gambar 2. Komponen Parameter DSAS (Sumber: USGS, 2009)

Penelitian ini menggunakan baseline yang tempatkan di wilayah daratan (onshore baseline). Shorelines terdiri dari garis pantai tahun 1964-2017. Transek yang membagi panjang shoreline dibuat mengarah ke laut dengan jarak transek $100 \mathrm{~m}$ dengan panjang transek $1 \mathrm{~km}$ dan jarak transek digunakan setiap 100-meter mengingat panjang garis pantai $\pm 49 \mathrm{~km}$, hal tersebut dianggap sudah detail untuk digunakan dalam pengukuran garis pantai. Jumlah transek yang membagi garis pantai kawasan Tuban bagian barat yaitu 491 transek, yang dikelompokkan menjadi 49 segmen (Gambar 1) berdasarkan transek yang mengalami dinamika perubahan garis pantai yang sama setiap tahunnya.

Metode analisis DSAS yang digunakan pada penelitian ini yaitu menggunakan Net Shoreline Movement (NSM), End Point Rate (EPR), Linear Regression Rate (LRR). NSM digunakan untuk perhitungan jarak perubahan garis pantai. EPR digunakan untuk perhitungan laju perubahan garis pantai (Sutikno,2014). LRR digunakan untuk prediksi perubahan garis pantai. Prediksi hanya dilakukan di area yang belum mengalami pembangunan seawall karena kawasan yang sudah terbangun pelindung pantai maupun bangunan permanen lainnya memiliki kecenderungan untuk tidak mengalami perubahan garis pantai yang signifikan.

Selain itu prediksi garis pantai juga memepertimbangkan hasil dari analisis
LRR yaitu jika koefisien determinasi memiliki nilai yang tinggi yaitu $\mathrm{R}>0,7$. Langkah selanjutnya adalah menentukan model regresi yang paling sesuai dengan cara melakukan regresi menggunakan variabel $\mathrm{X}$ sebagai tahun dan variabel $\mathrm{Y}$ sebagai jarak perubahan garis pantai masing-masing tahun dengan baseline. Hasil pengukuran perubahan garis pantai dengan DSAS menunjukkan nilai positif $(+)$ apabila mengalami akresi dan nilai negatif (-) apabila mengalami abrasi.

\section{HASIL DAN PEMBAHASAN}

Pemantauan Jangka Panjang Tahun 19642018

Pemantauan perubahan garis pantai jangka panjang dilakukan dari tahun 19642017 dengan analisis DSAS pada citra Landsat dan hasil survei lapang 2018 di Kabupaten Tuban bagian barat menunjukkan beberapa kawasan telah mengalami perubahan garis pantai yang signifikan (Gambar 3 dan 4). Hasil penelitian menunjukkan Desa SukoliloBoncong (segmen 2-25), Desa Purworejo (segmen 28), dan Desa Remen-Mentosa (segmen 36-37) mengalami akresi. Akresi terbesar terjadi di Desa Remen (segmen 35) dengan rata-rata jarak akresi sebesar 323,89 $\mathrm{m}$ dan rata-rata laju akresi sebesar 7,32 $\mathrm{m} /$ tahun. Penambahan daratan (akresi) yang signifikan di segmen 35 dan 46 disebabkan adanya reklamasi pembangunan UPT. Pelabuhan Perikanan 
Bulu di Desa Bulumeduro, Pelabuhan Indotama (PTTI) di Desa Remen dan Khusus PT. Trans Pasific Petrochemical terminal baru Desa Sugihwaras.

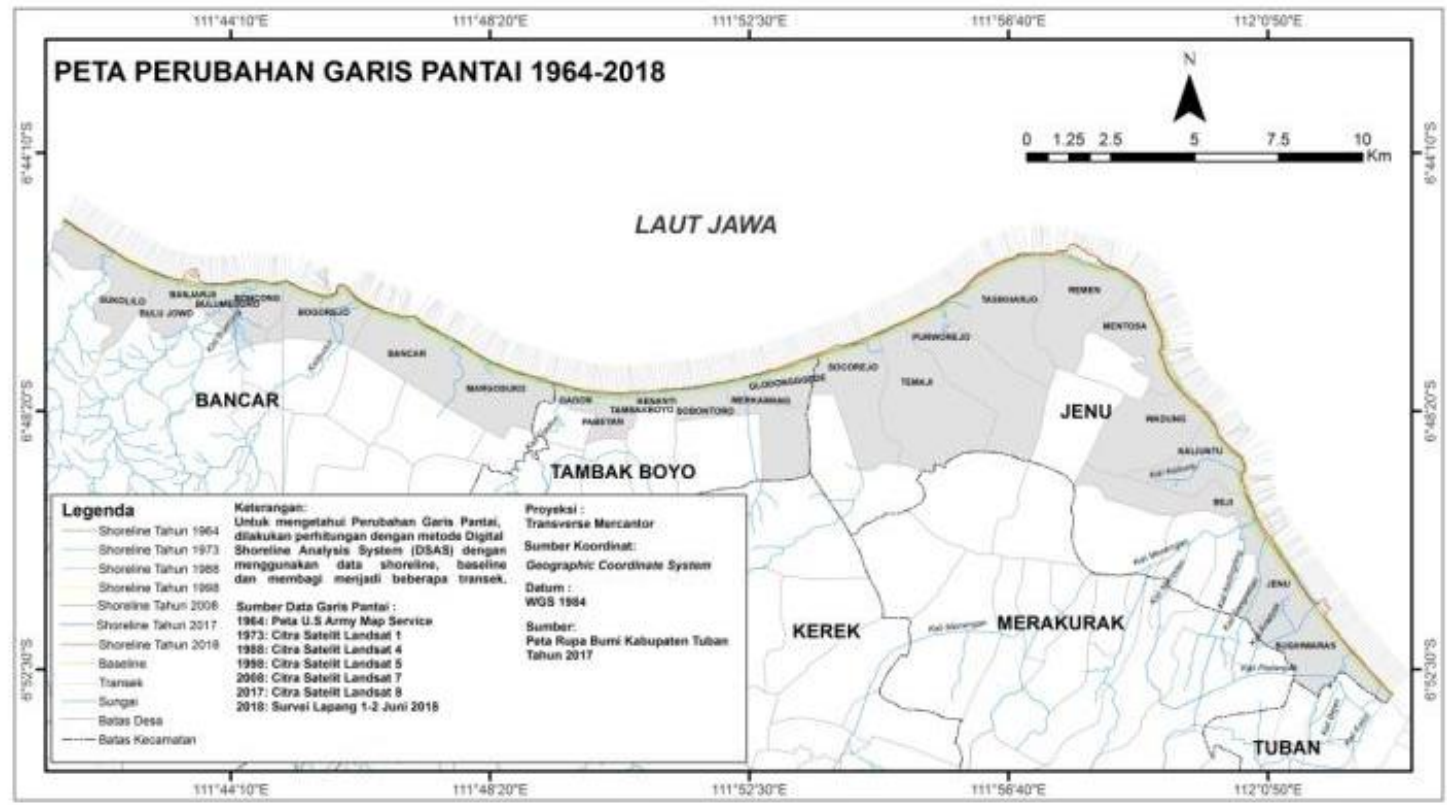

Gambar 3. Peta Perubahan Garis Pantai Tahun 1964-2018

Abrasi terbesar terjadi di Desa Tasikharjo (segmen 30), Desa Mentosa (segmen 38-41), Desa Jenu-Sugiwaras (segmen 45), dan Desa Sugiwaras (segmen 47 dan 49). Desa Mentosa (segmen 41) mengalami abrasi terbesar dengan rata-rata jarak abrasi sebesar $-181,90 \mathrm{~m}$ dan rata-rata laju abrasi sebesar $-4,11 \mathrm{~m} /$ tahun. Sedangkan segmen selain itu mengalami perubahan garis pantai yang dinamik dimana mengalami perubahan akresi dan abrasi. Kecamatan Bancar dan Kecamatan Tambakboyo pada tahun 1973-2017 dominan mengalami akresi hal tersebut karena sebagian besar sudah terbangun seawall, memiliki vegetasi pelindung berupa cemara laut dan terjadinya sedimentasi di muara sungai. Abrasi terjadi di sepanjang garis pantai Desa Mentosa-Sugihwaras masih minim ditemukan adanya bangunan pelindung pantai, dan sebagai alternatif pelindung pantai di kawasan ini yang belum terbangun seawall dilakukan dengan penanaman cemara laut, bakau dan penancapan patok kayu dan bambu sepanjang garis pantai.

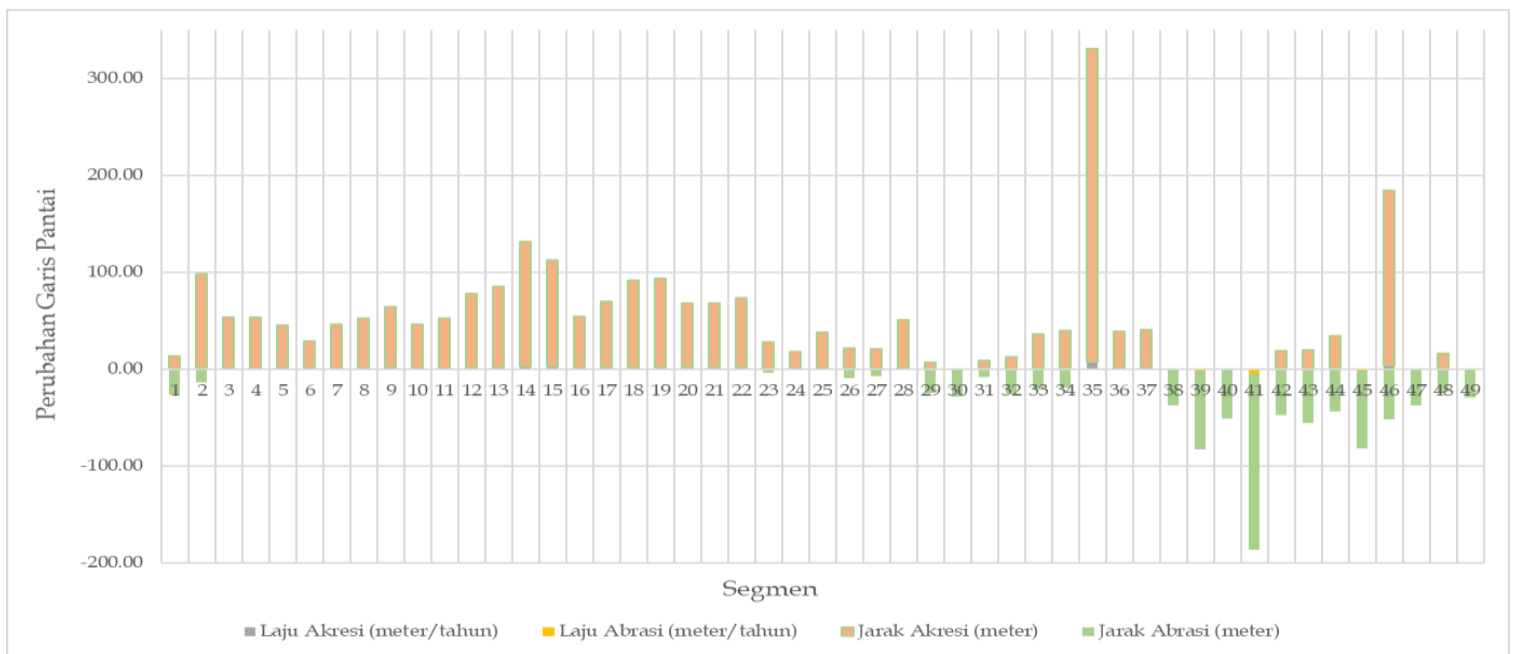

Gambar 4. Grafik Perubahan Garis Pantai Tahun 1964-2018 


\section{Pemantauan Perubahan Jangka Pendek Tahun 1964-1973}

Pada tahun 1964-1973 dikawasan pesisir Tuban bagian barat belum banyak dilakukan pembangunan skala besar pada wilayah pantai (Pelabuhan dan Reklamasi). Pemantauan perubahan garis pantai tahun 1964-1973 yang ditunjukkan pada Gambar 5, akresi terbesar terjadi pada Desa Mentosa (segmen 41) dengan rata-rata jarak akresi sebesar 133,08 $\mathrm{m}$ dan rata-rata laju akresi sebesar 16,63 m/tahun. Desa SocorejoSugihwaras (segmen 21-49) dominan mengalami akresi pendugaan ini dikarenakan tingkat sedimentasi yang tinggi di sekitar muara sungai Kali Untu, Kali Menengan, Kali Kedingding, Kali
Sangrahan, Kali Krapyak dan Kali Plalangan.

Desa Sukolilo-Boncong (segmen 2) mengalami abrasi terbesar dengan rata-rata jarak abrasi sebesar $-72,43 \mathrm{~m}$ dan rata-rata laju abrasi sebesar -9,05 (m/tahun). Perubahan garis pantai ditinjau dari seluruh garis pantai menunjukkan pada Desa Sukolilo sampai dengan Desa Glodonggede (segmen 1-20) dominan mengalami abrasi, diduga hantaman gelombang badai dan arus yang menyusuri pantai (longshore current) yang kuat pada saat musim hujan. Selain itu belum adanya pembangunan bangunan pelindung pantai berupa seawall juga turut mempercepat laju abrasi yang terjadi.

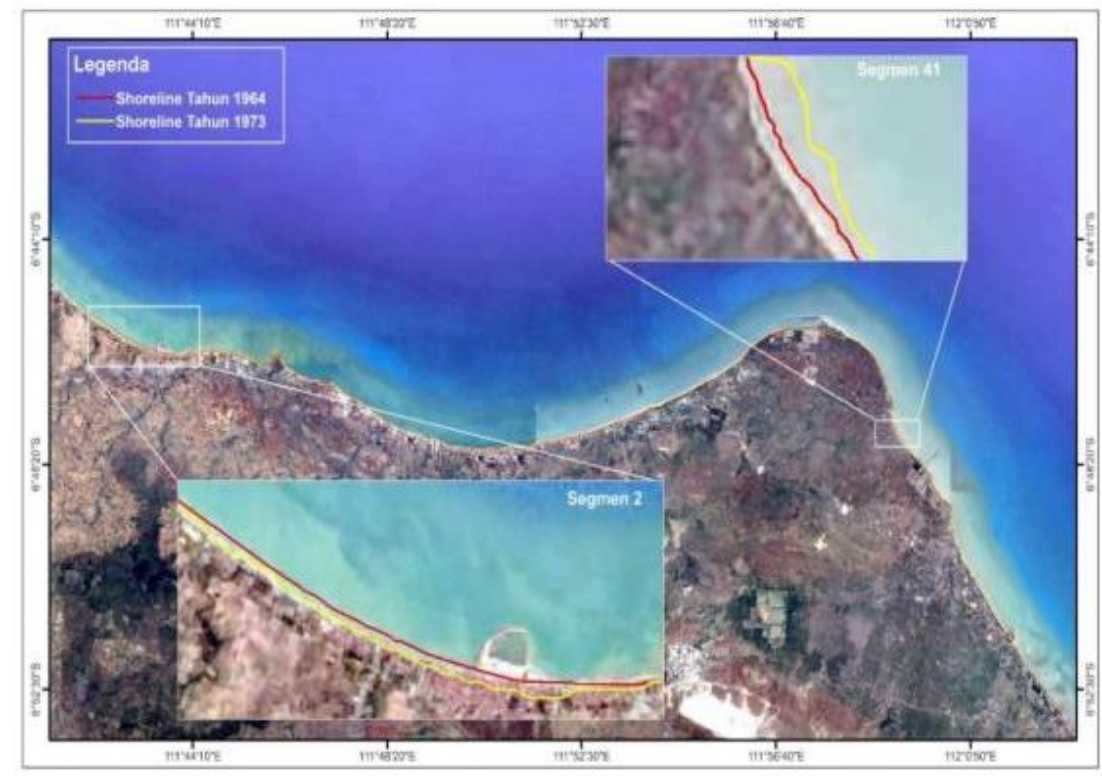

Gambar 5. Peta Perubahan Garis Pantai 1964-1973

\section{Tahun 1973-1988}

Aktivitas pembangunan yang massif di sepanjang garis pantai masih belum ditemukan pada tahun 1973-1988. Sebagian besar wilayah Pesisir Kecamatan Bancar, Kecamatan Tambakboyo dan Kecamatan Jenu dominan mengalami akresi (Gambar 6). Akresi tertinggi terjadi di Desa KaliuntuJenu (segmen 44) yang dengan rata-rata jarak akresi sebesar 141,98 $\mathrm{m}$ dan rata-rata laju akresi sebesar 9,41 m/tahun. Penyebab terjadinya akresi diduga disebabkan oleh tingkat sedimentasi yang tinggi pada daerah dekat muara sungai Kali Boncong,
Kali Budur, Kali Gadon, Kali Untu, Kali Menengan, Kali Kadingding, Kali Sangrahan, Kali Krapyak, dan Kali Plalangan.

Desa Mentosa pada segmen ke mengalami abrasi terbesar pada tahun 19731988 dengan rata-rata jarak abrasi pada segmen 41 sebesar $-94,29 \mathrm{~m}$ dan rata-rata laju abrasi sebesar $-6,25 \mathrm{~m} /$ tahun. Desa Purworejo-Remen dan Desa MentosaSugihwaras rentang mengalami abrasi hal ini diduga karena belum ada pembangunan pelindung pantai seperti seawall dan minimnya vegetasi pelindung seperti bakau 
dan cemara laut untuk memproteksi

kawasan pantai.

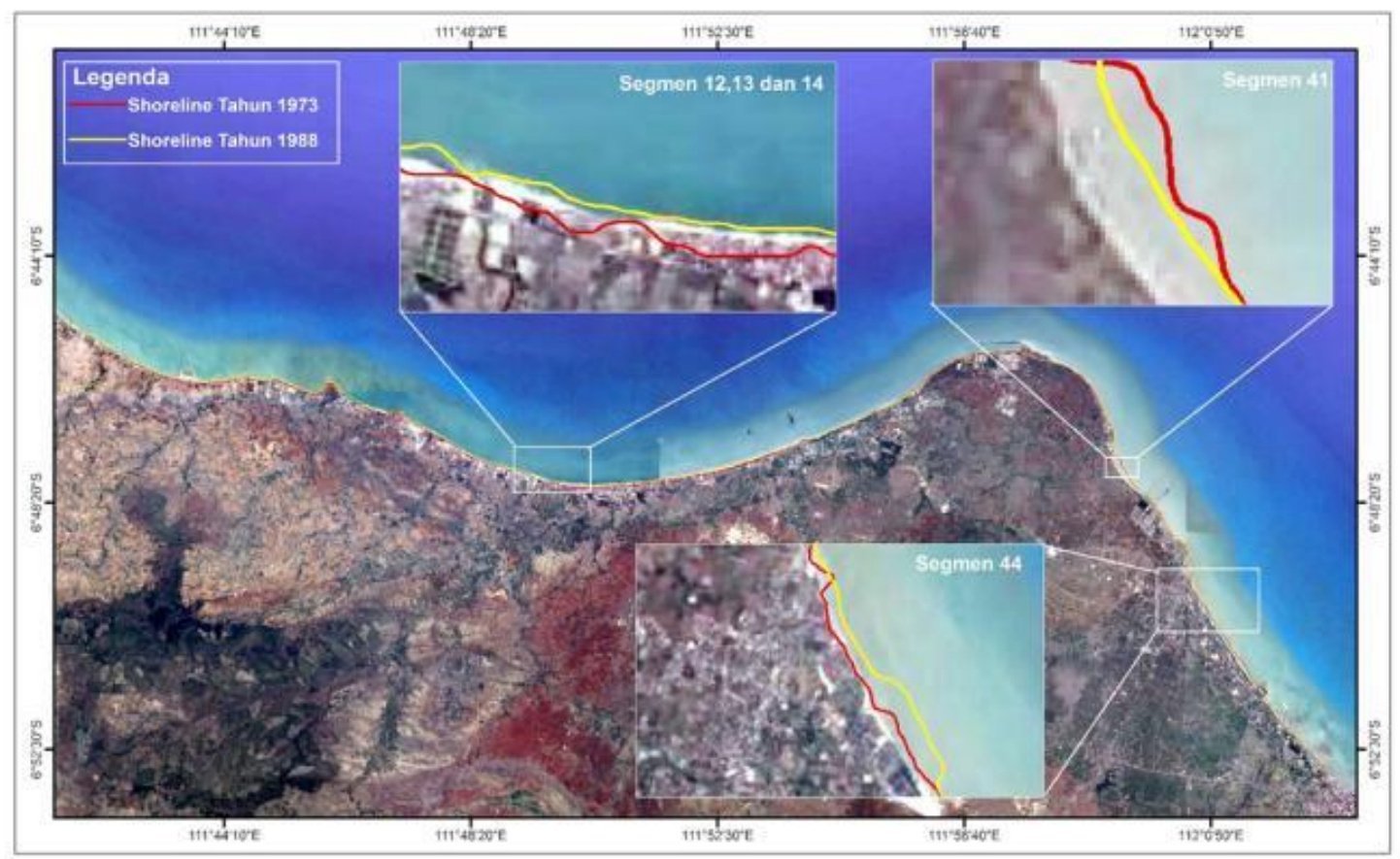

Gambar 6. Peta Perubahan Garis Pantai 1973-1988

Pemantauan perubahan garis pantai tahun 1964-1973 dan 1973-1988 menunjukkan adanya perubahan garis pantai yang signifikan. Pada Kecamatan Bancar dan Kecamatan Tambakboyo didominasi terjadinya abrasi, sedangkan hasil pemantauan tahun 1973-1988 seluruh kawasan Tuban bagian Barat dominan mengalami akresi. Hal ini diduga merupakan sifat dinamis dari alam sendiri, didukung dengan pernyataan Kalay, et al. (2014) yang menyatakan bahwa respon dinamis alami pantai terhadap laut dan daratan akan terjadi terus-menerus, jika ada faktor penghambat maka akan terjadi suatu kesetimbangan pantai, namun apabila dari waktu ke waktu tidak adanya kesetimbangan antara material pesisir dengan tekanan dari daratan dan laut maka akan terjadi perubahan yang signifikan, cenderung tidak stabil dan berdampak terjadinya kerusakan di daerah pantai.

\section{Tahun 1988-1998}

Pembangunan Pelabuhan Khusus milik PT. Semen Indonesia di Desa Socorejo
(Segmen 22) dan reklamasi pembangunan Pelabuhan khusus milik PT. Trans Pasific Pentrochemical Indotama (TPPI) di Desa Remen (segmen 35) menjadi faktor pendukung perubahan garis pantai tahun 1988-1998 (Gambar 7). Pembangunan tersebut menyebabkan akresi yang besar di Desa Remen (segmen 35) dengan rata-rata jarak akresi sebesar 191,86 m dan rata-rata laju akresi sebesar 18,57 m/tahun. Pembangunan pelabuhan berdampak terhadap perubahan transpor sedimen pada di Desa Remen bagian barat dan Desa Tasikharjo yang mengalami akresi.

Kawasan Pesisir Desa Kaliuntu-Jenu pada (segmen 44) mengalami abrasi terbesar dibandingkan dengan segmen lainnya, dengan rata-rata jarak abrasi sebesar -93,01 $\mathrm{m}$ dan rata-rata laju abrasi sebesar -9,0 m/tahun. Abrasi di Desa Kaliuntu-Jenu diduga karena pada kawasan tersebut belum memiliki bangunan pelindung pantai dan vegetasi pelindung pantai masih sangat minim. 


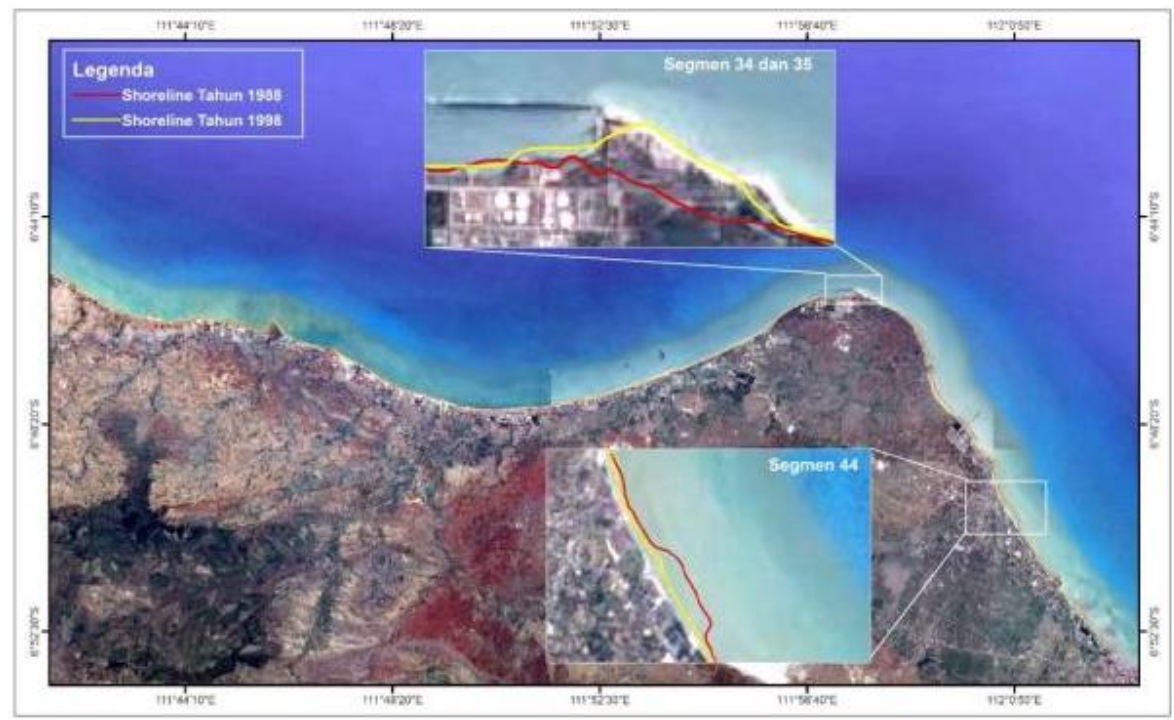

Gambar 7. Peta Perubahan Garis Pantai 1988-1998

\section{Tahun 1998- 2008}

Reklamasi pembangunan kawasan Pelabuhan Khusus PT. Trans Pasific Pentrochemical Indotama (TPPI) di Desa Remen dan Terminal Baru di Sugihwaras pada perubahan garis pantai tahun 19982008 (Gambar 8), memiliki dampak besar terhadap penambahan daratan (akresi) pada segmen 35 dan segmen 46. Hasil pemantauan perubahan garis pantai menunjukkan akresi terbesar terjadi Desa Sugihwaras (segmen 46) dengan rata-rata jarak akresi sebesar 242,54 m dan rata-rata laju akresi sebesar 23,62 $\mathrm{m} /$ tahun. Reklamasi tersebut berdampak terhadap perubahan pola transpor sedimen pada daerah yang berdekatan dengan kawasan reklamasi, yang relatif mengalami abrasi.

Sepanjang Desa Remen sampai dengan Desa Sugihwaras dominan mengalami abrasi (Segmen 37-49). Abrasi terbesar terjadi di Desa Mentosa (segmen 38) dengan rata-rata jarak abrasi sebesar 108,73 m dan rata-rata laju abrasi sebesar 10,59 m/tahun. Abrasi di Desa Mentosa diduga karena aktivitas penambangan pasir disekitar pesisir yang menyebabkan adanya pengurangan daratan, vegetasi pelindung yang masih minim dan belum terbangun seawall sebagai pelindung pantai.

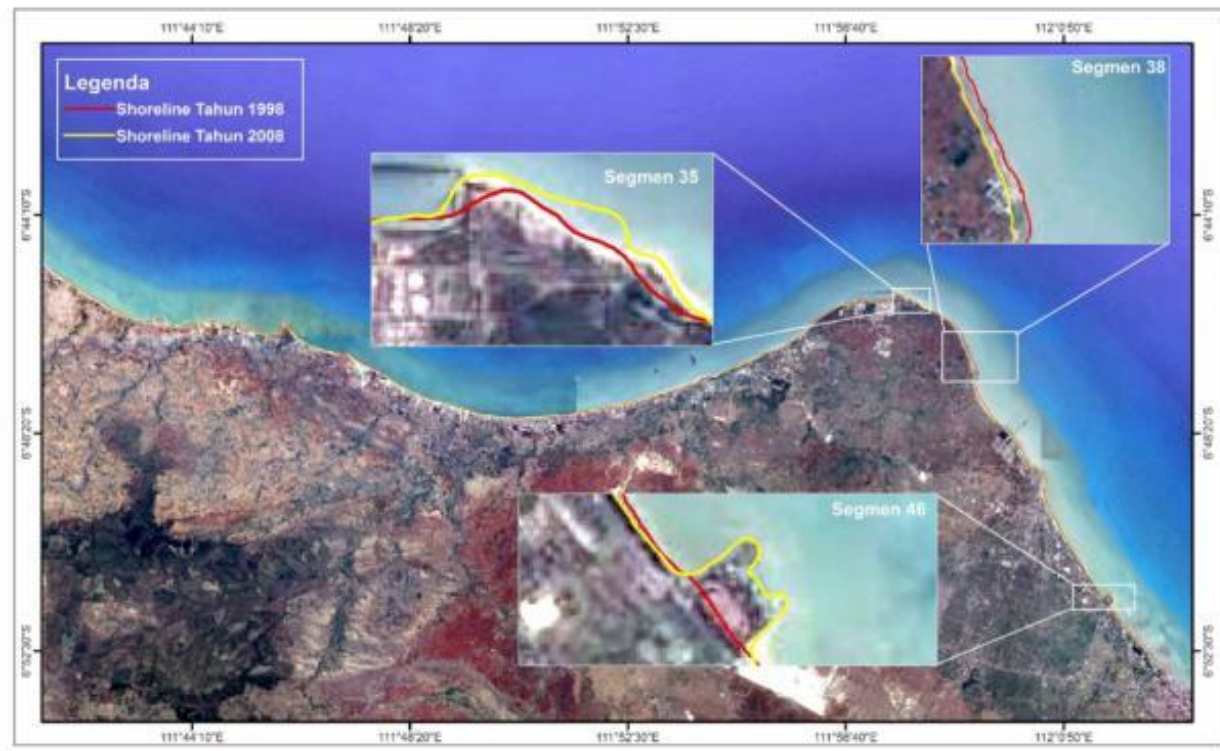

Gambar 8. Peta Perubahan Garis Pantai 1998-2008 


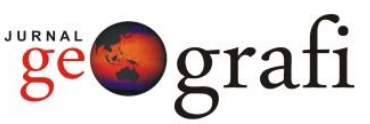

Tahun 2008-2017

Jetty pada Pelabuhan Khusus PT. Holcim, TBK., di Desa Markawang (segmen 17) dan PT. Semen Indonesia, TBK., di Desa Socorejo (Segmen 22) mempengaruhi sebaran sedimen di Desa Sobontoro-Temaji (Segmen 16-26). Hasil pemantauan garis pantai tahun 2008-2017 (Gambar 9) menunjukkan akresi tertinggi berada pada segmen ke 22 di Desa Socorejo, dengan rata-rata jarak akresi sebesar 56,42 $\mathrm{m}$ dan rata-rata laju akresi sebesar $6,59 \mathrm{~m} /$ tahun.

Pola transpor sedimen karena adanya pembangunan jetty pelabuhan khusus PLTU Tanjung Awar-awar berdampak terhadap terjadinya abrasi terbesar yg terjadi Desa Kaliuntu (Segmen 43) dengan rata-rata jarak abrasi sebesar $-78,34 \mathrm{~m}$ dan rata-rata laju abrasi sebesar $-9,14 \mathrm{~m} /$ tahun. Selain itu, adanya jetty pada pelabuhan Khusus Trans Pasific Petrochemical Indotama (PTTI) berdampak terhadap abrasi di Desa Tasikharjo-Remen (segmen 34) dan akresi di Desa Remen bagian timur.
Desa Sugihwaras mengalami akresi pada tahun 2008-2017, sedangkan pada tahun 1998-2008 terjadi abrasi sangat tinggi, penyebab dari perubahan garis pantai ini dikarenakan peningkatan perlindungan pantai di kawasan tersebut pernyataan ini didukung oleh penelitian tentang perubahan lahan setelah reklamasi terminal baru oleh Fathimah, et al. (2015), berdasarkan pemantauan dari tahun 20032014 menunjukkan telah terjadi perluasan penanaman cemara laut di barat terminal baru dan memperluas cemara laut kearah laut. Secara keseluruhan sepanjang garis pantai pada tahun 2008-2017 akresi lebih dominan dari pada abrasi, hal ini disebabkan karena sudah mulai ada bangunan pelindung pantai berupa seawall, penanaman vegetasi dan penancapan patok kayu di kawasan pesisir Kabupaten Tuban bagian barat.

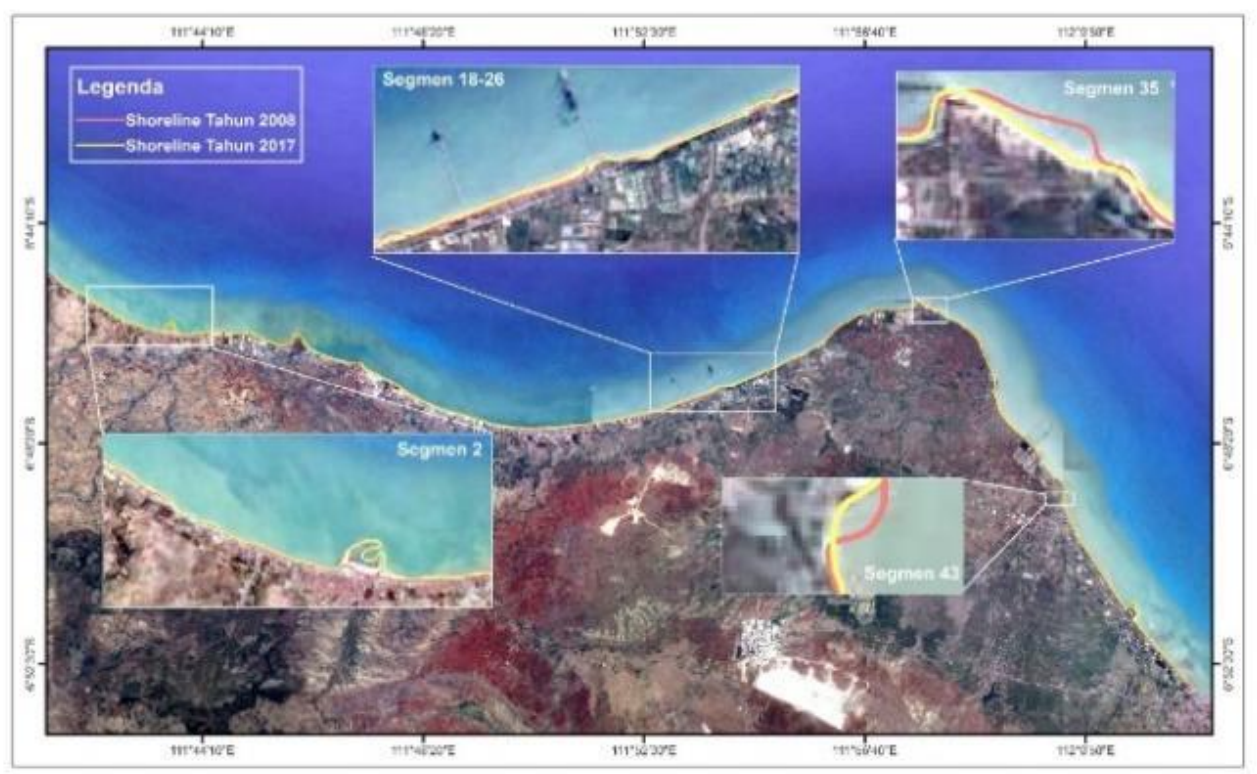

Gambar 9. Peta Perubahan Garis Pantai 2008-2017

Hubungan Pasang Surut Terhadap Garis Pantai

Pasang surut suatu perairan erat kaitanya dengan dengan perubahan garis pantai. Pasang surut pengalami perubahan dari waktu ke waktu, sehingga dapat merubah batas darat dan perairan yang digunakan sebagai titik acuan penentuan garis pantai (Kasim, 2012). Data garis pantai yang bersumber dari peta yang diterbitkan oleh Bakosutarnal dan bereferensi memiliki kondisi Mean Sea Level.

Hasil peramalan pasang surut pada citra Landsat dapat dilihat pada Tabel 2. 
Data citra yang mengalami kondisi surut adalah tahun 1973, 1988, 1998 dan 2017. Namun pada data citra landsat tahun 2008 pada kondisi pasang dikarenakan keterbatasan data Landsat 7 yang menyediakan data kisaran tahun 2007-2008 memiliki tutupan awan $<40 \%$. Kondisi
Pasang surut pada citra Landsat yang akan dilakukan penelitian perubahan garis pantai sebaiknya memiliki kondisi pasang surut yang sama. Hal tersebut bertujuan untuk mengasilkan data perubahan garis pantai yang lebih akurat.

Tabel 2. Kondisi Pasang Surut Saat Akuisisi Citra Satelit

\begin{tabular}{cccccc}
\hline \multirow{2}{*}{ Satelit } & Tanggal & WTC & WIB & \begin{tabular}{c} 
Kondisi \\
Pasang \\
\cline { 3 - 5 }
\end{tabular} & $\begin{array}{c}\text { Surut } \\
\text { Kedalaman } \\
(\mathbf{m})\end{array}$ \\
\hline Landsat 1 & $10 / 10 / 1973$ & $02: 07: 52$ & $09: 07: 52$ & Surut & $-0,28$ \\
Landsat 4 & $29 / 12 / 1988$ & $02: 13: 59$ & $09: 13: 59$ & Surut & $-0,16$ \\
Landsat 5 & $14 / 10 / 1998$ & $09: 20: 45$ & $09: 20: 45$ & Surut & $-0,60$ \\
Landsat 7 & $26 / 05 / 2008$ & $09: 31: 51$ & $09: 31: 51$ & Pasang & 0,21 \\
Landsat 8 & $28 / 06 / 2017$ & $09: 41: 42$ & $09: 41: 42$ & Surut & $-0,10$ \\
\hline
\end{tabular}

Sumber : Pemodelan Pasang Surut dengan TMD, 2018

\section{Keterkaitan Geomorfologi Pantai dengan Perubahan Garis Pantai}

Perubahan geomorfologi pantai dapat disebabkan karena dinamika kemiringan pantai dan distribusi sedimen yang menyebabkan terjadinya abrasi dan akresi pada pantai (Kalay, et al., 2014). Pengukuran kemiringan pantai di lapang dilakukan pada Pantai Bulu (Desa Bulumeduro), Pantai Bancar (Desa Bancar), Pantai Gadon (Desa Gadon), Pantai Surindah (Desa Temaji), Pantai Pasir Putih (Desa Remen), Pantai Mentosa (Desa Mentosa) dan Pantai Cemara (Desa Sugihwaras). Klasifikasi kemiringan pantai menunjukkan pada Pantai Bulu, Pantai Bancar, Pantai Gadon dan Pantai Surindah termasuk ke dalam pantai datar dengan rata-rata kemiringan $1,94^{\circ}$. Klasifikasi pantai landai yaitu pada Pantai Pasir Putih dan Pantai Mentosa dengan rata-rata kemiringan 3,59 . Menurut Kalay, et al. (2014) besarnya kemiringan pantai mengindikasikan suatu kawasan tersebut memiliki gelombang pecah yang cukup besar yang dapat menyebabkan terjadinya abrasi pada sepanjang garis pantai. Hal ini didukung pada saat survey pada Pantai
Remen yang merupakan pantai yang paling besar kemiringannya menunjukkan bahwa memiliki gelombang cukup tinggi, sehingga dalam pengukurannya tidak memungkinkan dilakukan pengukuran sepanjang $30 \mathrm{~m}$.

Akresi di Kecamatan Bacar, Kecamatan Tambakboyo dan Kecamatan Jenu sebagian besar terjadi pada daerah dekat muara sungai, dekat reklamasi pantai, jetty, daerah yang ditanami cemara laut dan daerah yang sudah terbangun seawall. Abrasi pada kawasan ini sebagian besar terjadi di kawasan yang tidak memiliki bangunan permanen (seawall) dan daerah yang berdekatan dengan jetty. Hasil ground check di Pesisir Tuban bagian Barat, kawasan yang mengalami akresi yaitu di daerah yang sudah terbangun seawall yaitu Desa Sukolilo-Boncong, Desa Gadon, Desa Sobontoro, dan Desa Kaliuntu. Kawasan yang terkena dampak terhadap adanya pelabuhan khusus yaitu pada garis pantai Desa Temaji dan Desa Socorejo, bangunan disekitar pesisir mengalami kerusakan di kawasan pesisir (Gambar 10). 

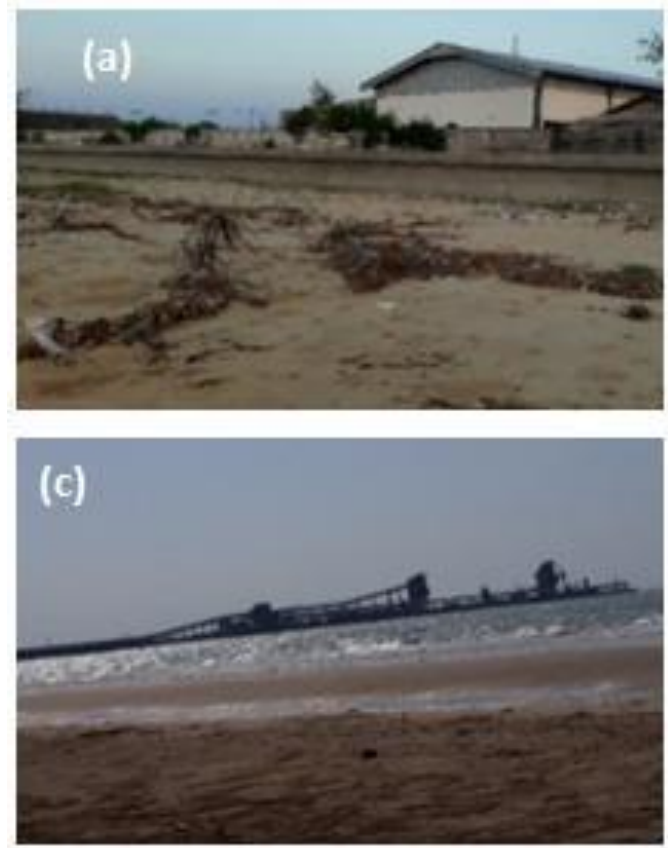
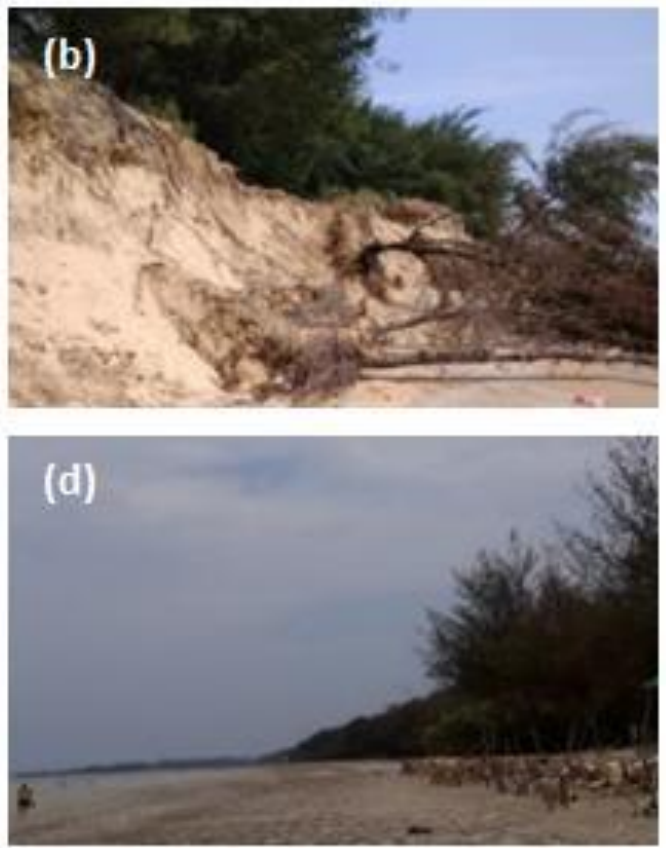

Gambar 10. (a) Seawall Desa Sobontoro (b) Kerusakan Pesisir Desa Sobontoro (c) Jetty Pelabuhan Khusus PT Semen Gresik. TBK., (d) Cemara Udang Desa Sugiwaras

\section{Prediksi Perubahan Garis Pantai}

Prediksi perubahan garis pantai untuk 10 tahun kedepan yang pada tahun 2028 (Gambar 11) menunjukkan akresi tertinggi terjadi pada Segmen 18 di Desa Glodonggede dengan rata-rata laju akresi sebesar 2,25 m/tahun. Abrasi terbesar terjadi pada segmen 41 di Desa Mentosa dengan rata-rata laju abrasi sebesar $-4,63$ $\mathrm{m} /$ tahun. Prediksi perubahan garis pantai menunjukkan Kecamatan Bancar dan Kecamatan Tambakboyo diindikasikan pada tahun 2029 akan dominan mengalami akresi (penambahan daratan) sedangkan Kecamatan Jenu yang diindikasikan mengalami akresi yaitu pada Desa SocorejoRemen dan yang diindikasikan mengalami abrasi (pengurangan daratan) yaitu pada Desa Mentosa, Desa Wadung, Desa Jenu dan Desa Sugiwaras. Prediksi perubahan garis pantai dapat terus terjadi apabila kawasan tidak mengalami perubahan penggunaan lahan atau campur tangan dari manusia.

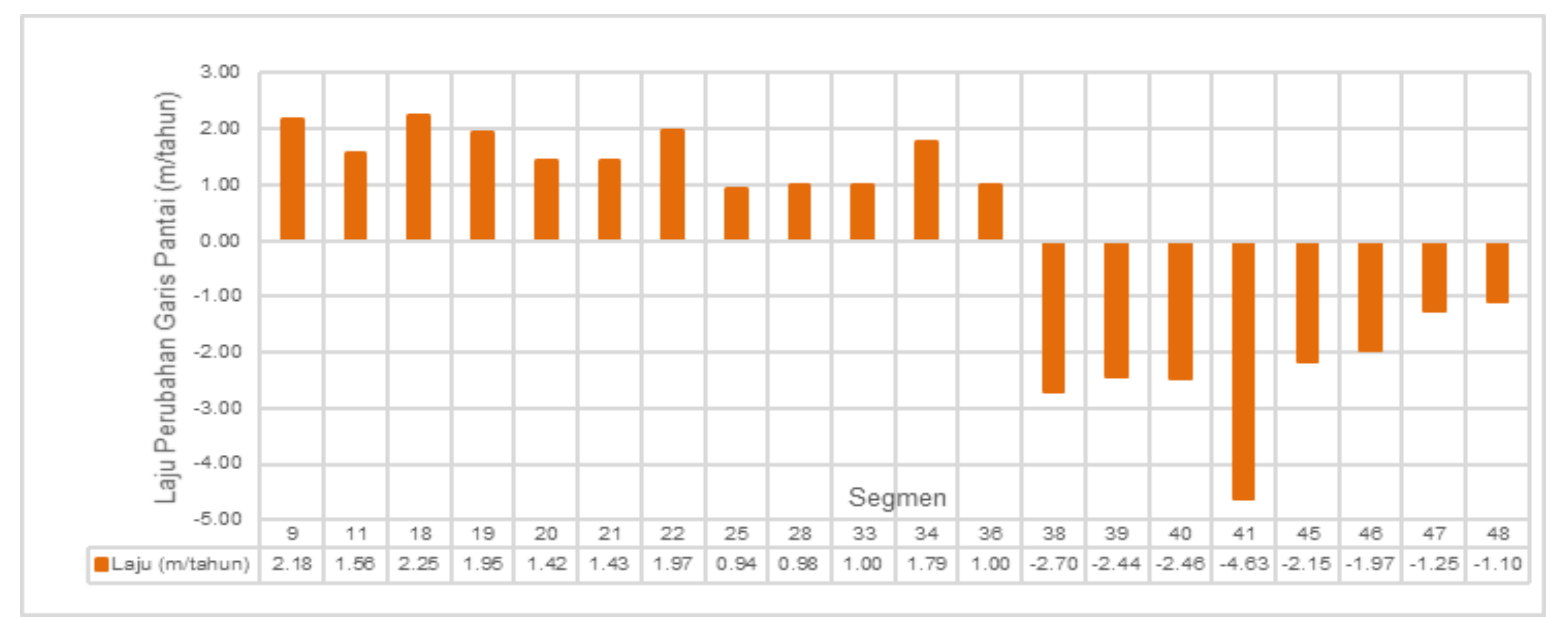

Gambar 11. Prediksi laju perubahan garis pantai untuk 10 tahun ke depan (2019) 


\section{KESIMPULAN}

Kesimpulan yang dapat diambil dari penelitian ini yaitu sebagai berikut:

1. Pesisir Kabupaten Tuban bagian Barat pada tahun 1973-2017 mengalami perubahan garis pantai akresi yang ditunjukkan dengan nilai positif $(+)$ dan abrasi yang ditunjukkan dengan nilai negatif (-). Akresi terbesar terjadi pada segmen 35 yaitu terletak di Desa Remen dengan rata-rata jarak akresi sebesar 323,89 $\mathrm{m}$ dan rata-rata laju akresi sebesar 7,32 $\mathrm{m} /$ tahun. Sebaliknya abrasi terbesar pada segmen 41 yaitu terletak di Desa Mentosa dengan rata-rata jarak abrasi sebesar $-181,90 \mathrm{~m}$ dan rata-rata laju abrasi sebesar $-4,11 \mathrm{~m} /$ tahun.

2. Prediksi perubahan garis pantai Tahun 2029 mengindikasikan akresi terbesar akan terjadi pada segmen 18 di Desa Glodonggede dengan perkiraan ratarata laju akresi sebesar $2,25 \mathrm{~m} /$ tahun. Sebaliknya abrasi terbesar akan terjadi pada segmen 41 di Desa Mentosa dengan perkiraan rata-rata laju abrasi sebesar $-4,63 \mathrm{~m} /$ tahun.

\section{UCAPAN TERIMA KASIH}

Penelitian ini dibiayai oleh Lembaga Penelitian dan Pengabdian kepada Masyarakat (LPPM) Melalui Dana Penerimaan Negara Bukan Pajak (PNBP) Universitas Brawijaya Sesuai dengan Daftar Isian Pelaksanaan Anggaran (DIPA) UB Nomor DIPA-042.01.2.400919/2018.

\section{DAFTAR PUSTAKA}

Arief , M., Winarso, G. \& Prayogo, T. (2011). Kajian Perubahan Garis Pantai Menggunakan Data Satelit Landsat di Kabupaten Kendal. Jurnal Penginderaan Jauh, Volume 8, pp. 7180.

Fuad, MAZ. Setiani, M.A. (2017). Automatic Detection of Decadal Shoreline Change on Northern Coastal of Gresik, East Java - Indonesia. IOP
Conference Series: Earth and Environmental Science, Volume 98, conference 1

Hidayati , N. (2017). Dinamika Pantai. Malang: UB Press.

Istiqomah, F., Sasmito, B. \& Amarrohman, F. J. (2016). Pemantauan Perubahan Garis Pantai Menggunakan Aplikasi Digital Shoreline Analysis System (DSAS) Studi Kasus Pesisir Kabupaten Demak. Jurnal Geodesi UNDIP, Volume 5 (1), pp. 78-89.

Ji, L. et al. (2015). Target Detection Method for Water Mapping Using Landsat 8 OLI/TIRS Imagery. Water, Volume 7, pp. 794-817.

Kalay, D. E., Manilet, K. \& Wattimury, J. J. (2014). Kemiringan Pantai dan Distribusi Sedimen Pantai di Pesisisir Utara Pulau Ambon. Jurnal TRITON, Volume 10 (2), pp. 91-103.

Kasim , F. \& Salam, A. (2015). Identifikasi Perubahan Garis Pantai Menggunakan Citra Satelit serta Korelasinya dengan Penutupan Lahan di Sepanjang Pantai Selatan Provinsi Gorontalo. Jurnal Ilmiah Perikanan dan Kelautan, Volume 3 (40, pp. 160-167.

Marfai, M. A. et al. (2011). Model Kerentanan Wilayah Pesisir Berdasarkan Perubahan Garis Pantai dan Banjir Pasang (Studi Kasus : Wilayah Pesisir Pekalongan). Yogyakarta: UGM.

Pranoto, S. (2007). Prediksi Perubahan Garis Pantai Menggunakan Model Genesis. Berkala Ilmiah Teknik Keairan, Volume 13 (3), pp. 145-154.

Richard. (2015). Perubahan Garis Pantai dan Kerusakan Pantai di Kawasan Kepesisiran Kabupaten Tuban Bagian Barat. Jurnal Bumi Indonesia, Volume 4 (4).

Setyawan , W. B. (2001). Karakteristik Sumberdaya dan Proses Pesisir : Alasan Perlunya Kerjasama dalam 
Mengelola Wilayah Pesisir. Energi, Sumberdaya Alam dan Lingkungan.

Suniada, K. I. (2015). Deteksi Perubahan Garis Pantai di Kabupaten Jembrana Bali dengan Menggunakan Teknologi Penginderaan Jauh. Jurnal Kelautan Nasional, Volume 10 (1), pp. 13-19.

Sutikno, S. (2014). Analisis Laju Abrasi Pantai Pulau Bengkalis dengan Menggunakan Data Satelit. ResearchGate.

USGS. (2009). Digital Shoreline Analysis System. s.l.:s.n.

$\mathrm{Xu}, \mathrm{H}$. (2006). Modification of Normalised Difference Water Index (NDWI) to Enhance Open Water Features in Remotely Sensed Imagery. International Journal of Remote Sensing, Volume 27 (14), pp. 3025-3033. 